\title{
CREATING AND SURVIVING IN NEW INDUSTRIES*
}

\author{
Rajshree Agarwal \\ Department of Business Administration \\ University of Illinois at Urbana Champaign \\ 350 Wohlers Hall, 1206 S. Sixth St. \\ Champaign, IL 61820 \\ (217) 265-5513 \\ agarwalr@uiuc.edu
}

\author{
Barry L. Bayus \\ Kenan-Flagler Business School \\ University of North Carolina at Chapel Hill \\ Chapel Hill, NC 27599 \\ (919) 962-3210 \\ Barry_Bayus@UNC.edu
}

invited paper for Advances in Strategic Management, 21

(Business Strategy Over the Industry Life Cycle; J. Baum and A. McGahan, eds.)

forthcoming 2004

\begin{abstract}
New industries are created from the pioneering activities of a few firms. These firms generally face great uncertainty and risk, but also stand to benefit from early mover advantages due to the preemption of resources. Based on an empirical analysis of a diverse set of consumer and industrial innovations introduced in the US over the past 100 years, we find that entrants during the pre-firm take-off stage (termed Creators) have higher survival rates than later entrants that enter between the firm and sales take-off (termed Anticipators), and both of these entrant types have higher survival rates than firms that enter after the sales take-off (termed Followers). Notably, survival rates for Creators and Anticipators do not depend on entry time within the cohort group, i.e., what matters is whether an entrant enters before or after the take-off, not whether it entered first in its cohort. Our results indicate that there is no real option value in waiting when one considers survival as a performance measure, which bodes well for firms interested in creating new industries.
\end{abstract}

\footnotetext{
* We thank Joel Baum, Raj Echambadi, Anita McGahan and Anju Seth for their insightful comments. All remaining errors are ours.
} 


\section{INTRODUCTION}

New industries for product innovations hold the promise of great rewards, but at the same time are fraught with risk and uncertainty. The decision of when (or whether) to enter a new industry can be a critical determinant of a firm’s long term survival (e.g., Christensen 1997). Interest in the question of whether there are market performance advantages for pioneers over later followers has led to a number of survey papers (Kalyanaram, Robinson, and Urban 1995; Kerin, Varadarajan, and Peterson 1992; Lieberman and Montgomery 1998; Robinson, Kalyanaram, and Urban 1994), as well as meta-analyses (e.g., Szymanski, Troy, and Bharadwaj 1995; Vander Werf and Mahon 1997).

Conventional wisdom in the strategy literature suggests that while early entrants may have higher returns (e.g., market share) they also have higher risks of failure relative to later followers due to the greater uncertainty inherent in a new industry (e.g., Lieberman and Montgomery 1998; Mitchell 1991; Shepherd 1999) ${ }^{1}$. In particular, there is often uncertainty concerning whether there is sufficient demand to sustain survival in the formative stages of industry evolution, along with technological uncertainty related to essential product features and functionality (Christensen 1997; Lambkin and Day 1989; Utterback 1994). Later followers can wait until more information about market attractiveness is revealed, and thus can frequently minimize their R\&D and marketing costs associated with entry (Mitchell 1991; Yip 1982). These followers can learn from the mistakes of the pioneers, and consequently, have higher survival probabilities over early entrants. This line of thought is generally summarized by statements like "market pioneers are the ones with arrows in their backs” (Robinson and Min 2002) or “first to market, first to fail” (Golder and Tellis 1993) and resonates with literature in real options (e.g., Bernanke 1983; Miller and Folta 2002) that there may be value in deferring entry timing in the presence of uncertainty.

\footnotetext{
${ }^{1}$ Though research in economics (Agarwal and Gort 1996) and marketing (Robinson and Min 2002) provide some evidence to the contrary.
} 
Some natural questions arise as a result of this reasoning. Why would a firm decide to enter in the early stages of a new industry? How is any new industry established? Is industry creation and firm survival related? Based on the preemption of resources argument, a number of potential advantages associated with early entry into a new industry have been proposed, including establishing brand loyalty and high switching costs, locking up distribution channels and suppliers, setting up patent protection, capturing scale economies, and establishing technology standards (Kerin, Varadarajan, and Peterson 1992; Lieberman and Montgomery 1998; Robinson and Min 2002). These possible first-mover advantages rely on a (temporary) monopoly of the pioneer over later entrants, and as a result, much attention in empirical studies has centered on defining a single market pioneer (Golder and Tellis 1993; Robinson and Min 2002). However, this stream of research can be criticized on two major grounds. First, identifying a single pioneering firm using archival records is generally problematic since many entrepreneurs/inventors who actually commercialize a device shortly after its invention go unrecorded (Khan and Sokoloff 1993; Lamoreaux and Sokoloff 2002). Moreover, accurately dating the beginnings of any particular product innovation is controversial (Freeman, Clark, and Soete 1982; Rosenberg 1994). Second, many new industries do not have a single pioneering firm and the monopoly period, if it exists, is generally short (Agarwal and Bayus 2002). Thus, in addition to the theoretical tension between resolution of uncertainty and preemption of resources, measurement challenges imply that the relationship between early entry, industry creation and firm survival is still not clear.

The purpose of this study is to further explore the factors related to firm survival in new industries. Our methodology allows us to simultaneously address issues related to the resolution of uncertainty and definition of entry cohorts. We base our study on the premise that key turning points in industry evolution provide valuable information relating to technological and demand uncertainty 
about the viability of the new industry, and also serve to delineate cohort groups of firms. We begin by integrating literature on the diffusion of firms (e.g., Gort and Klepper 1982) and sales (Mahajan, Muller, and Bass 1990) with a focus on the "take-off” points (Agarwal and Bayus 2002; Golder and Tellis 1997) and consider the survival rates of entry cohorts at different points in the industry life cycle. Following (Agarwal and Bayus 2002), we operationalize the life cycle stages for a new industry based on three distinct, sequential time periods: the time between commercialization and a sharp increase or "take-off" in the number of competing firms, the time between firm and sales takeoff, and the time after sales take-off. Each of these periods, we argue, represent successive resolution of technological and demand uncertainty. We examine whether entrants during the pre-firm take-off stage (termed Creators) have higher survival rates than later entrants that enter before sales take-off (termed Anticipators), and whether entrants during the post-sales take-off stage (termed Followers) have lower survival rates than either the Creators or Anticipators.

To empirically investigate the relationship between industry creation and firm survival for these three industry life cycle stages, we consider data for a set of consumer and industrial product innovations introduced into the US over the last 100 years. After controlling for various industry and firm factors, we find evidence that Creators have the highest survival rates, followed by the Anticipators and Followers. Thus, the results indicate that there is no real option value in waiting, at least when one considers survival as a performance measure, which bodes well for firms interested in creating new industries. Further, the factors related to survival for firms entering in each of these stages are found to differ. In particular, survival in the pre-firm take-off stage depends primarily on firm density (i.e., for firms entering in this stage, survival is negatively related to competition) whereas survival in the stage between firm and sales take-off primarily depends on firm size and age (i.e., for firms entering in this stage, there is a liability of newness as well as smallness). Notably, 
survival in either of these early stages does not depend on entry time within the cohort group, i.e., what matters is whether an entrant is part of the Creator or Anticipator cohort, not whether it entered first in that cohort.

\section{CREATORS, ANTICIPATORS AND FOLLOWERS IN NEW INDUSTRIES}

Patterns of firm diffusion in evolutionary economics and organizational ecology studies typically characterize the industry life-cycle in terms of an initial growth period, followed by a shakeout, maturity and decline (e.g., Agarwal and Gort 1996; Gort and Klepper 1982; Klepper and Graddy 1990; Klepper and Simons 1997; Rosegger and Baird 1987; Utterback and Suarez 1993; Utterback 1994). Most of these studies lump the early entrants together as entering in the growth stage, i.e. they do not necessarily distinguish between the firms that enter in the initial "monopoly" period where there are at most very few firms competing in the newly created industry, and firms that enter in the following period characterized by a sharp take-off in the number of firms. As a result, prior research is unable to examine the performance of the true industry creators, as distinguished from firms that enter later, though still early in the industry life cycle. Moreover, the focus of this research stream has primarily been on firm diffusion rates, and thus does not directly consider sales diffusion. A parallel literature stream in marketing has focused on sales diffusion curves, with the industry life cycle being defined purely in terms of the number of consumers that enter the market over time (e.g. Bass 1980). Interestingly, this stream of literature also finds a take-off in new industries, where a "hockey-stick" pattern in sales diffusion is used to depict the early stage of the life-cycle of really new technological products (Golder and Tellis 1997; Mahajan, Muller, and Bass 1990; Moore 1991).

The take-off points in both the number of firm and sales represent important landmarks in the early period of an industry life cycle, since each represent some resolution of uncertainty regarding the viability of the product innovation as a new industry. Integrating the firm and sales diffusion 
curves, we define entry cohorts based on when the firm and sales take-off points occur. In this context, we begin by reviewing relevant findings on the take-off in firms and sales from our earlier study (Agarwal and Bayus 2002).

To be considered for inclusion in this study, a consumer or industrial product innovation had to be deemed significant by experts in the field, and result in entirely new product-markets rather than improvements or sub-sections of existing markets. Accurate historical data on new industries are typically very difficult to obtain, and even harder is the task of matching sales and price information to data on entry and the number of firms competing in the industry. Consistent time series data on a set of key variables for 30 product innovations introduced in the U.S. between 1849 and 1983 was compiled (see Table A1 for a list of the new industries). These 30 new industries encompass a broad spectrum of important products introduced over the past 150 years, and include a diverse mix of consumer and industrial products, as well as products that vary in their capital and technological intensiveness. In addition, the product innovations we study overlap with those studied by other researchers (i.e., Golder and Tellis 1997; Gort and Klepper 1982). Since secondary data is used, it can be argued that only "successful” industries are considered. However, this concern is mitigated by the fact that new industries empirically exhibit a wide variation in the time to sales take-off. Since several industries in our sample take well over twenty years before achieving a take-off, industries that could have been considered "failures" based on their very low sales in the early years of formation are included in our sample.

In Agarwal and Bayus (2002), we identify the two take-off times for 30 product innovations by using a generalized version of discriminant analysis ${ }^{2}$. These data indicate that the take-off times

\footnotetext{
${ }^{2}$ Briefly, this methodology allows us to distinguish between any two consecutive intervals by examining the data on annual percentage change in sales (for the sales take-off) and annual net entry rates (for firm take-off) for each product. To determine the take-off year for a product, we first partition the appropriate series into three categories---the first and third categories contain the years where the percentage change in sales or net entry rate clearly reflect the pre- and post-
} 
in firms and sales are clearly related: firm take-off systematically precedes sales take-off for every product we considered ${ }^{3}$. Theoretically, this finding is consistent with the idea that firm entry affects both supply (due to increases in capacity and process improvements) and demand (due to non-price competition arising from quality improvements, advertising and infrastructure development), resulting in unambiguous increases in sales of the product innovation. Figure 1 empirically illustrates this pattern for two products, and Figure 2 summarizes key descriptive statistics from our earlier study.

[Insert Figure 1 here]

[Insert Figure 2 here]

While there is significant variation across industries, the mean time between commercialization and firm take-off is just over six years. On an average, over half of the competitors in each year before the firm take-off tend to be new entrants (from Figure 2, the average annual entry rate between commercialization and firm take-off is $55 \%$ ). However, relative to the peak number of firms over the observed product life cycle, these firms still represent only $13 \%$ of all potential competitors (see the Relative \# Firms Ratio in Figure 2, defined as the ratio of the number of firms to the peak number of firms over the observed product life cycle).

On average, the take-off in sales occurs eight years after firm take-off. We also find that $44 \%$ of all the competitors in a new industry enter before the take-off in sales. Thus, firm entry decisions seem to be related to anticipated profit, rather than actual profits, with more than $30 \%$ of all potential competitors entering in the period between firm and sales take-off. While over half of a new market's eventual competitors do enter after the sales take-off, these results strongly suggest that the

take-off periods, respectively. Periods for the "in-between" years are then optimally classified based on mean values. See Gort and Klepper (1982) for details.

${ }^{3}$ For 26 of the 30 products in our sample, the time of firm take-off preceded the time of sales take-off by at least three years. 
monopoly period for a product innovation is brief at best, and occurs well before the product growth stage. Based on the estimated exponential price trends for each innovation, Figure 2 also reports that the percentage change in price between commercialization and year prior to firm take-off is $-31 \%$, and between firm and year prior to sales take-off is $-40 \%$. Clearly, prices tend to decline over time for product innovations.

Our prior analyses suggest some stylized facts that are consistent with other studies. Firm entry impacts not only supply, but also demand for a new product innovation. In particular, based on the two take-off times of firms and sales respectively, we can distinguish between three types of entry cohorts: Creators, Anticipators, and Followers. Immediately after the first commercialization of the product, efforts of the very early entrants — the Creators-are geared towards generating demand for the new product. Early entrants often bring crucial new information, skills and product quality improvements (Gort and Klepper 1982). This is particularly important since the early commercialized forms of new innovations are generally quite primitive (e.g., Klepper 1996; Rosenberg 1982; Rosenberg 1994; Shapiro 1986; Thomson 1986). For instance, Klepper (2004) found that a range of entrants, with varying types of pre-entry experiences, were valuable in shaping the industry evolution of the automobile industry, since no one individual organization was distinguished on all dimensions. In addition to the studies examining broad indicators of product quality improvements through early entry across several product-markets (e.g. Gort and Konakayama 1982; Klepper and Simons 1997), detailed evidence of the relationship between early firm entry and product improvements is also available from various industry case studies (e.g., Christensen 1993; Utterback 1994). For example, Murray and Tripsas (2004) find evidence that creators engage in focused attempts and experiments at developing and commercializing radically new technologies. We note that the role of demand creation played by early entrants is also consistent with the literature in organizational ecology 
(Hannan and Carroll 1992; Hannan and Freeman 1989), and the turbulence and ferment attributed to this era in technology management studies (Henderson and Clark 1990; Tushman 1986).

Another stylized fact that seems to emerge is that firms perceive the potential opportunities before consumers, since a significant percent of entrants in the new industry enter before the take-off in sales. We note that while consumers may appreciate the potential value of a product innovation, the actual realization may require firms to offer a threshold level of quality, as well as affordable prices, before a substantial number of consumers will be interested in making a purchase. As indicated by Adner (2004), the performance or quality threshold is a function of expectations, tastes, task requirements and existing substitutes. Thus, the second entry cohort, the Anticipators of demand, are often crucial to expand the consumer base, since their strategies may help develop consumer acceptance and any necessary supply chain infrastructure (e.g., Bayus and Putsis 1999; Brown 1981). Competition during this stage is primarily on the basis of continued product improvements (e.g., see reviews in Geroski 1991; Geroski 1995; Klepper 1996), and results in a further increase in perceived product quality. Extensive advertising and promotion can help educate and inform potential consumers about the benefits of a new product innovation, and as suggested by Brown (1981), sales take-off for a product innovation may also be related to the existence and evolution of an industry infrastructure. New distribution channels and pricing arrangements may be necessary for some innovations (e.g., sewing machines required the establishment of new retail outlets as well as credit terms). Widespread adoption of product innovations often requires the development of complementary products and services (e.g., automobiles needed roads and gas stations). These fundamental infrastructure developments often take place as a result of new entry into the industry, either as new information is brought in by entrants or as competitive strategies of incumbents to stave off entry. This is consistent with the demand view of technology S curves 
(Adner, 2004), since efforts at increasing performance levels bring about more consumers whose are now willing to pay for the technology that meets a threshold level of performance. Thus, the combined efforts of the Creators and Anticipators alike help to create industry growth opportunities. The beneficial aspects of competition during these two stages are evidenced by outward shifts in both the demand and supply curves (rather than supply alone), resulting in an unambiguous increase in sales but an indeterminate price effect. While the summary statistics in Figure 2 indicate a general downward trend in price, this ambiguity in price effects can possibly account for actual industry cases such as turbojet engines, cathode ray tubes and microwave ovens in which sales took off even though prices were increasing. Importantly, as we find in Agarwal and Bayus (2002), demand shifts due to the non-price factors associated with new firm entry is a key driver of take-off in sales, since firm entry dominates price as an explanatory variable of take-off times.

A third stylized fact that emerges is that the take-off in sales represents the realization of the value opportunities of the product innovation in the eyes of the consumers, resulting in continuing entry by the Follower cohort. These firms, however, increase the competitive stakes due to an accompanying shift in focus from product to process improvements and resultant price competition (Klepper 1996). Since diminishing willingness to pay for additional performance improvements characterizes demand for most products (Adner, 2004), firms may choose to focus on reducing price in addition to, or instead of, improving quality. For instance, the history of the automobile industry shows that the majority of process improvements came after 1909 (the year of sales take-off in the industry), with the most dramatic improvements in manufacturing occurring after the sales take-off when Ford pioneered the moving assembly line around 1913 (see Klepper and Simons 1997, Klepper, 2004). This is consistent with the dominant design literature in technology management (Tushman 1986; Utterback and Abernathy 1975), the phenomena of firm shakeout in evolutionary economics 
(Agarwal and Gort 1996; Gort and Klepper 1982; Klepper and Simons 1997), and the effects of firm density and increasing competitive pressures in organizational ecology (Baum 1995; Carroll and Hannan 1989; Hannan and Freeman 1989).

As would be expected from the above discussion, both the firm and sales take-off occur in the growth stage of the traditional industry life cycle. The shake-out in the industries we study, if it does occur within the sample period, ensues on average of 15 years after the sales take-off (the minimum we observe is six years after the sales take-off).

\section{ENTRY TIMING AND SURVIVAL}

In this section, we further explore the performance implications of firm entry in the three different periods of the industry landscape (prior to firm take-off, between firm and sales take-off and after sales take-off). As the above discussion suggests, the timing of both take-off points is dependent on firm entry as well as their post-entry strategies, thus we recognize that there are potential issues related to the endogeneity of the take-off phenomenon and entry timing. We assume that, while the collective decisions of firms do shape the industry structure within which they operate, ex-ante, firms entering the industry are uncertain about the industry evolution. We further assume that the behavior of any one firm is not sufficient to alter market conditions by itself. Since this may be a restrictive assumption (particularly if the firms entering the industry are large relative to the industry size or if the density of firms is high), we examined the correlations of the length of time until firm and sales take-off to the average firm size and density during these periods. None of these correlations are significant at the $5 \%$ level, thus alleviating to some degree concerns regarding the realism of our assumptions. However, as we note in the conclusions, a detailed consideration of the endogeneity issue is an important topic for further research. 
As discussed briefly in the introduction, there is considerable ambiguity regarding (first) early mover advantage. This is not only attributable to the theoretical rationale for both early mover advantages and disadvantages (Lieberman and Montgomery 1998; Lieberman and Montgomery 1988), but also to differences in empirical methodologies relating to the definition of early (first) mover and sample selection (Golder and Tellis 1993; Kalyanaram, Robinson, and Urban 1995; Robinson and Min 2002). Theoretically, the existence of early mover advantages hinges on (a) preemption — if entering early affords superior access to geographic, technological or consumer perceptual space, then the early entrants gain significant advantages (Lieberman and Montgomery 1988) and (b) uncertainty—if entering early implies entering in an environment fraught with significant demand and technological uncertainty, then there may be value in deferring commitment and waiting to enter (Bernanke 1983; Ghemawat 1991; McGahan 1993). The latter aspect relates to the real options perspective regarding increases in the option value of waiting and postponing investments with increases in uncertainty (Ingersoll and Ross 1992; McDonald and Siegel 1986).

The uncertainty facing the three cohort groups is clearly different. The Creators face the highest level of risk and uncertainty since the sales potential of the new industry is unclear. Relative to the creators, the firms in the anticipator cohort have more information, since they benefit from a resolution of some of the risk and uncertainty. For example, resolved uncertainty about technology may result in the Anticipators gaining a technological edge in processes, since they are not locked in (e.g., Ghemawat 1991) to a production approach that is suboptimal. However, there may still exist some demand uncertainty, particularly if the first movers are able to keep proprietary the updated information they receive on demand based on their incumbent status (McGahan 1993). Since both entry cohorts enter before the explosion in sales growth, committing early versus retaining flexibility (Bernanke 1983; Ghemawat 1991) is akin to deciding on whether to undertake an option to wait 
(Ingersoll and Ross 1992; McDonald and Siegel 1986; Miller and Folta 2002; Trigeorgis 1991). The last group, the Followers, enter after the customer value proposition is established, and consequently face lower levels of uncertainty relative to the earlier entry cohorts. Indeed, some of the entrants in both the anticipator and follower cohort group may represent employee entrepreneurship (Klepper, 2004), and thus a transfer of technological or demand knowledge from industry incumbents to their progenies (Agarwal, Echambadi, Franco and Sarkar, forthcoming).

The downside to waiting for the resolution of uncertainty is the risk of preemption (Lieberman and Montgomery 1988). Miller and Folta (2002) show that an early exercising of the option to enter may occur not only as a preemptive strike, but in order to reduce rivals' option value of the entry timing decision. In the context of our three entry cohorts, this leads to some intriguing speculations. If preemption of resources is the overriding factor and crucially related to entry timing, then the Creators should be the most advantaged group. If, however, uncertainty resolution and preemption of resources are both important, then "waiting a little, but not too long” may result in optimal performance. In this case, one could argue that the Anticipator cohort benefits from a window of opportunity. Finally, if the resolution of the uncertainty in both technology and demand dictates performance, then the Follower group should benefit in terms of higher performance. Thus, examining the survival probabilities of the three groups allows us to shed light on the performance implications of a preemption strategy (committing early) to a flexibility strategy (waiting for information on market potential).

Before turning to the empirical analysis, it is also important to address some methodological issues that have resulted in ambiguous results in the early mover advantage literature, particularly in the context of firm survival as a performance measure. Golder and Tellis (1993) criticize some of early studies on early mover advantages based on the misidentification of the early market leaders as 
market pioneers, and Shepherd (1999) states, based on a review of the strategy literature, that pioneers enjoy higher returns if successful, but bear a higher risk of failure. Robinson and Min (2002) find higher survival rates for the market pioneer in industrial goods, based on a selection of industries in which one firm could clearly be identified as pioneering the market. Since many industries have more than one market pioneer, and moreover, have very short monopoly intervals (Agarwal and Bayus 2002), it is important to generalize this finding. We circumvent the above issues by distinguishing between entry cohorts based on their entry timing after commercialization vis-à-vis industry growth ${ }^{4}$. If early industry leaders rather than the pioneers are indeed the firms that have higher survival probabilities, then our empirical analysis will find higher probabilities of survival associated with the Anticipators, rather than the Creators.

\section{EMPIRICAL ANALYSIS}

\section{Data Description}

Data for our analysis is chiefly obtained from the Thomas Register of American Manufacturers. A detailed description of the data source and the compilation of the firm level database is contained in Agarwal, Sarkar, and Echambadi (2002) and Agarwal and Bayus (2002). Since our analysis requires comprehensive data on the census of firms that operated in the industry over the entire life cycle and requires knowledge of sales diffusion within the industry, our sample is limited to 22 new industries (see Table A1 in the appendix). All of the 22 industries are included in our earlier study, and we refer interested readers to Agarwal and Bayus (2002) for a detailed description on the calculation of take-off times and other industry characteristics.

\footnotetext{
${ }^{4}$ In Table A1, we report an estimated an "invention” year for each product innovation based on several published sources (e.g., Giscard d’Estaing 1986) and analyses (e.g., Jewkes, Sawers, and Stillerman 1958; Enos 1962; Mensch 1979; Kohli, Lehmann, and Pae 1999). We recognize, however, that there is considerable controversy over the accuracy of dating inventions (e.g., Freeman, Clark, and Soete 1982; Rosenberg 1994). Despite the measurement challenges, enhancing our understanding of the pre-commercialization development activities within new industries presents some excellent future research opportunities.
} 
In addition to the names and addresses of firms, the firm-level data for the 22 industries contains the following information: year of entry, year of exit, asset size for each year of operation, and diversification (whether or not the firm had any prior industry experience). We also ensured that the entries did not include existing firms that had merely been renamed or relocated. Since spin-offs or spin-outs (Klepper, 2004; Agarwal et al., forthcoming) represent independent ventures, they are considered as new entrants. Identifiable mergers and acquisitions were treated as the continuance of the larger firm and exit of the smaller firm (Mansfield 1962; Robinson and Min 2002). The final database of firms consists of a total of 2,427 firms pooled across the product innovations, resulting in 25,606 firm/year observations.

\section{Method}

We test our hypotheses by examining hazard rates, or the probability of the firm not surviving another year contingent on attaining a particular age. A firm's hazard rate, $\mathrm{h}(\mathrm{t})$ is defined as the probability that it will die in a particular time interval $(t+\Delta t)$, given that it has survived until t, i.e. ,

$$
h(t)=\lim _{\Delta t \rightarrow 0}[\operatorname{Pr}(t, t+\Delta \mid t] / \Delta t
$$

We model the firm's hazard rate $h_{f}(t)$ as a function of the explanatory variables as follows:

$$
h_{f}(t)=h\left(t ; x_{f}\right)=\exp \left(x_{f}^{\prime}(t) \beta\right)
$$

where $x_{f}$ is a vector of measured explanatory variables for the $\mathrm{f}^{\text {th }}$ firm, and $\beta$ is a vector of parameters to be estimated. Several discrete and continuous time analyses are available for the estimation of hazard rates (Allison 1995). Consistent with earlier studies (Baum and Oliver 1991; Henderson 
1999), we use a multiple spells formulation with a complementary log-log specification ${ }^{5}$. The instantaneous probability of failure of a firm at time $t$ in this model is given by

$$
h(t)=1-\exp \left[-\exp \left(\beta x_{t}\right)\right]
$$

To ensure robustness of our results, we also examined alternative model specifications (including probit, logistic, Cox proportional hazards). Although not reported here, the results are very similar across the different model specifications.

\section{Variables and Measures}

\section{Firm Failure (Dependent Variable)}

For each firm/year observation, our dependent variable of firm failure is coded as 1 , if the firm exited the industry in a given year, and 0 otherwise.

\section{Entry Relative to Take-off Time}

Based on our prior discussion, we distinguish firms based on their entry during three periods during the industry life cycle. The dummy variable Creator is coded as 1 , if the firm entered before the firm take-off, and 0 otherwise. The dummy variable Anticipator is coded as 1 , if the firm entered after firm take-off but before sales take-off, and 0 otherwise.

\section{$\underline{\text { Firm-level Variables }}$}

Firm-level variables in our analysis include firm age, firm size, whether or not the firm had any pre-entry experience and timing of entry. For each year of the firm's existence, Age is calculated as the number of years since the time of entry into the industry. To account for any non-linear effects of age, both linear and quadratic terms for age are included in the model. Firm size at time of entry is measured by the asset size listed by the Thomas Register in each year of its existence. Since the time

\footnotetext{
${ }^{5}$ Although a firm may fail at any point within a given year, the data on failure are updated only annually. A multiple spells, complementary log-log formulation allows continuous-time hazard rates to be obtained from discrete time failure data. See Allison (1995) for details.
} 
period over which firm entry is sampled encompasses almost the entire twentieth century, we adjusted the asset categories for inflation and classified size into five categories ${ }^{6}$. These asset categories (expressed in 1982 dollars) are (a) less than \$2 million, (b) \$2 to 4 million, (c) \$4 to 6 million, (d) \$6 to \$8 million, and (e) greater than $\$ 8$ million. We distinguish between "small” and "large" firms by classifying firms as small if they are in the smallest asset category. ${ }^{7}$ Our measure for diversifying entrants was obtained by consulting the firm index of annual volumes of the Thomas Register in the year preceding a firm's entry into the relevant industry. The variable De alio at Entry is coded as 1 for firms with pre-entry experience, and 0 otherwise. For Timing of Entry, we use the logarithm of year from time of industry commercialization to control for observed wide variation in this measure across industries (see Suarez and Utterback, 1995; Agarwal et al., 2002). We note that our results are largely robust to a linear specification. $\underline{\text { Industry-level Variables }}$

We include 21 industry dummy variables to control for any industry specific fixed effects. To control for variations over time, we include contemporaneous firm density. In a longitudinal study that pools several industries, density heterogeneity across industries makes it inappropriate to represent these variables by the raw annual count of firms competing in an industry (Agarwal, et.al 2002). Accordingly, we compute relative density measures defined as the firm density in a particular year divided by the peak density observed in an industry. The peak density is used as a divisor since it represents the carrying capacity of the industry, or the number of firms sustainable in an industry given its resource base. Thus, the closer the relative density number is to one, the more indicative it is

\footnotetext{
${ }^{6}$ The producer price index (all commodities) is used as a deflator, since it is the only PPI that dates back to the beginning of the century. We note that using the consumer price index as a deflator does not change our conclusions.

${ }^{7}$ We also experimented with alternative operationalizations of size by identifying firms as small if their size is less than the $60^{\text {th }}$ percentile of the size distribution for all firms entering in a given decade (using midpoints of the size intervals and their logarithmic transformations). Our results are robust to these different specifications.
} 
of competitiveness and a scarce resource environment. To account for non-linear effects, both linear and quadratic terms for contemporaneous density are used in the model.

\section{Results}

Table 1 includes the descriptive statistics and correlation matrix for the main variables we consider. Before turning to the formal analysis, we begin by reporting some summary statistics regarding survival rates in Table 2. The five year survival rate is $72 \%$ for Creators, $67 \%$ for Anticipators, and $60 \%$ for Followers; these are significantly different at the $1 \%$ level. These preliminary statistics indicate that Anticipators and Followers do not necessarily enjoy the benefits of an option to wait. In this context, it is also interesting to examine the timing of exit for each cohort group. Do Creators tend to die before firm take-off or later after Anticipators and/or Followers enter? Similarly, do Anticipators tend to die prior to sales take-off or do they die after Followers enter? From Table 2, we see that the timing of exit for the Creator group is relatively uniform, though slightly increasing as the industry evolves. Further, we find that Creators are relatively long-lived (11\% of the Creators survived through all stages and had not exited by the end of the sample period). Among the Anticipators, there is a bigger difference in the percent that exit before (37\%) and after (49\%) sales take-off. Still, $13 \%$ of the Anticipators also survive until the end of the sample period. Among the Followers that enter post sales take-off, 70\% subsequently exit the industry. The statistics in Table 2, however, should be treated with caution, since they do not control for firm and industry characteristics that can affect survival. In particular, the last column reporting the percent not exiting the industry by end of sample period should be interpreted carefully; while the Followers seem to have the highest percentage of survivors, they are also the most recent cohort and have not withstood the passage of time as much as the earlier entry cohorts.

[Insert Table 1 here] 
[Insert Table 2 here]

To systematically investigate firm hazard rates, we turn to an analysis of the probability of firm failure reported in Table 3. The coefficient estimates for Model 1 confirm the presence of an early mover advantage. Relative to the firms entering after the sales take-off, firms that enter before the firm take-off (i.e., Creators) have the lowest probability of failure, followed by the firms that enter between firm and sales take-off (i.e., Anticipators) ${ }^{8}$. Thus, firms that wait for the firm take-off to signal industry viability and feasibility do not seem to enjoy any real option advantages from waiting, and do no better than Creators when survival is used as a measure of performance.

However, Anticipators do benefit from earlier entry vis-à-vis firms that enter after sales has taken off (i.e., the Followers).

\section{[Insert Table 3 here]}

Regarding firm specific factors, experience reduces the probability of failure. This includes both experience prior to entry in the market (De alio at Entry) and tenure in the focal market (Age). Firms that diversify into the new industry fare better than de novo firms, and age decreases the probability of failure consistently over a firm's tenure in the industry. Surprisingly, and contrary to the literature, we find that small firms at the time of entry enjoy lower probabilities of failure. The non-linear effects of firm density, however, suggest that initial increases in firm density act as a "legitimizing" effect, but further increases cause competitive pressures.

The results from Model 1 shed light on the issue of whether confounding definitions may have resulted in prior contradictory findings on first mover advantage. As noted previously, the

\footnotetext{
${ }^{8}$ We tested whether the coefficients for the firms entering prior to firm take-off and entering between firm and sales takeoff are equal. A likelihood ratio test rejects the null hypothesis at the $1 \%$ level, indicating that the two cohorts are not homogenous. Also, regardless of which group of firms is treated as the control (baseline) group, our analysis reveals that the coefficients of the dummies representing the stage of entry relative to take-off times are significantly different from each other. Further, our results are robust when the observations from industries for which sales take-off occurs very close to firm take-off are dropped from the analysis.
} 
existing literature often groups entry cohorts differently, and the definitions are not always

consistent. In particular, some studies on pioneering advantages misclassify the entrants and use data available only after sales has already taken off. Also, studies that use firm diffusion curves do not pay attention to the importance of sales diffusion. These studies lump firms that enter between firm and sales take-off in the same category as firms that enter post take-off.

The importance of correctly grouping entry cohorts is further evidenced by the sub-group results reported in Models 2 through 4 in Table 3. In addition to the firm and industry factors included in Model 1, we consider the timing of entry within each cohort to test whether entering earlier in that particular life cycle stage affects the probability of failure. Models 2 through 4 reveal significant differences between the Creators, Anticipators and Follower cohorts. In particular, we note that most of the results on firm and industry factors affecting survival in Model 1 apply either to the Anticipators or to the Followers, but not the Creators. Firm heterogeneity in resources among Creators does not lead to appreciable differences in performance, since firms that enter with a smaller size or without prior experience are not adversely affected in their probabilities of survival. Further, within this cohort, timing of entry does not matter-whether the firm was a true pioneer or a second or third entrant is not related to the probability of failure. What matters, however, is that a firm enters before the take-off in firms (as seen in Model 1). In terms of industry factors, only the squared firm density term is significant. This indicates that competitive pressures later in the industry life cycle do adversely affect firm performance.

Firm factors do matter for the other two entry cohorts, and interestingly, in different ways. In particular, we find that while being small does not matter among Creators, or may even be beneficial among the late movers (where small firms may occupy strategic niches), it definitely hurts the Anticipators that enter between the firm and sales take-off. In other words, during the crucial 
"middle” period still fraught with uncertainty, larger firms have the necessary resources to continue developing the nascent industry and can make the most of the opportunities in the industry. For the Anticipators, the existence of pre-entry experience per se is not important, but experience within the industry (Age) does prove beneficial. Pre-entry experience is particularly beneficial for firms that enter after the industry takes off, but does not help either the Creators or the Anticipators. As with the Creators, timing of entry within the cohort group is not a significant factor for Anticipators. As long as a firm enters prior to the sales take-off, its survival probability is enhanced relative to the Follower group. Interestingly, there are no significant effects of firm density on the firms that enter between firm and sales take-off. This perhaps indicates that the Anticipators do not benefit from the potential "legitimizing" effects of firm density, and because they are anticipating demand correctly, they are also insulated in some sense from any competitive pressures.

Perhaps the most intriguing finding in Model 4 of Table 3 is the negative and significant effect of Timing of Entry for the Follower cohorts. This indicates that rather than a linear model of timing or order of entry, there exists the presence of strong non-linearity. Firms entering immediately after sales take-off may have waited too long, since they find themselves unable to capture the benefits of either creating or anticipating the demand. Facing entrenched competitors who have already established the necessary infrastructure or brand recognition among consumers, these firms may well have entered during the height of competitive activity, and thus find themselves most at risk. Their performance is also seen to be the most affected by the pressures of firm density than any of the other two cohorts. We note that our findings on the negative effects of Timing of Entry in the last entry cohort is consistent with the density delay argument in organizational ecology, the effects of firm shake-out in evolutionary economics, and the establishment of the dominant design in technology management. However, once the industry matures, there exist opportunities for 
successful entry, particularly in niche markets. Taken together, Models 1 and Model 4 in Table 3 indicate that; (1) entering before the sales take-off is generally desirable, and (2) if entry does occur after the sales take-off, it is better to enter later than earlier. These results imply that absent crucial information on take-off times in a new industry, analyses of firm performance should include nonlinear terms for timing of entry, similar to Echambadi, Sarkar, Agarwal and Arroniz (2003). This is confirmed by the estimation results reported in Table 4 in which the entrant cohort dummy variables are replaced by a continuous Time of Entry variable. Here, Model 1 reveals an insignificant coefficient for Timing of Entry when only a linear term is considered, while Model 2 reports highly significant coefficients when a non-linear specification is employed. The positive and significant linear term and the negative and significant quadratic term in Model 2 indicates that entering early or late is beneficial, but entering in the middle is detrimental to survival. We also note that the inclusion of the non-linear term for Timing of Entry causes the size effects to disappear, supporting our conjecture that small firms that enter late and occupy strategic niches are the ones that may have caused the mis-specified linear model to show that small firms are advantaged over large firms.

[Insert Table 4 here]

\section{Conclusions}

We believe these empirical results imply that firm survival in new industries is positively related to being involved in the creation of a new industry. The firms that participate in the early definition of the product value proposition have higher long-term survival rates than later entrants. We speculate that the Creators are able to shape and mold the early definition of a product innovation to better match their capabilities and core competencies; this endows some of the Creator firms with a competitive advantage over later entrants. This is also consistent with the findings of Murray and Tripsas (2004) that entrepreneurial firms engage in focused experimentation aimed at resolving the 
technological and demand uncertainty that characterizes radically new technologies. Not surprisingly, survival during this early period in which sales are very low is primarily dependent on the existence of adequate competitive space (i.e., the chances of survival are high when competitive density is relatively low).

In addition, firms that participate in the delivery and implementation of the already defined product value proposition have higher long-run survival rates than later Followers. Firms that enter before the take-off in sales anticipate that there is a real market opportunity associated with the product innovation. We speculate that it is during this stage of industry evolution that firms can establish positioning and marketing advantages through their advertising and distribution strategies. Survival for firms entering during this stage when sales are still low but competition is increasing depends on firm size. The chances of survival are the highest for larger firms with greater resources, and, not surprisingly, it is the larger firms that are more able to spend money on advertising and distribution. Also, there is a liability of newness associated with entrants during this stage, i.e., survival rates improve for firms that are able to endure the initial few years. Finally, our empirical results for firm survival after sales take-off are consistent with a general strategy of product differentiation. Survival for later Followers is highest for firms that are able to establish a competitive niche or market segment in the maturing industry.

Our study points to future directions for research in the area. While our study found no evidence of an option value in waiting to enter in terms of survival rates, the literature would benefit from a similar investigation of profitability as a performance measure. As noted in the introduction section, there may be a trade-off between survival and profitability based on timing of entry. Early entry may afford higher profitability due to the same factors that enhance survival. Alternatively, 
lower costs of entry for Followers may result in their profits being potentially higher than the earlier cohorts, thus creating an option value for waiting in terms of their return on investment.

A limitation of our study, particularly when interpreting the effect of firm resources and capabilities on survival, is that we have not explicitly considered the endogeneity of entry timing and firm survival. Thus, if heterogeneity of firm resources and capabilities affect a firm's entry timing decision, then the true relationship between firm factors and performance is not captured in our analysis. However, our study also points to the endogeneity of market structure to the strategies undertaken by the different entry cohorts. Thus, entry timing itself may result in differences in firm resources and capabilities. This is a particularly important area of future research, and suggests a need for modeling dynamic capability acquisition that takes into consideration the feedback effects of strategy and competition on market structure. For instance, in a recent study, Miller and Folta (2002) suggest that collusion among firms that results in delaying entry timing may be beneficial to each firm. However, the present study, in conjunction with our earlier research (Agarwal and Bayus 2002), highlights the possible endogeneity of industry growth. This suggests that the longer firms wait to enter a new industry, the longer it will take for the industry potential to be realized in the form of a sales take-off. While it may be beneficial for firms to cooperate in order to jointly increase market size, colluding to defer entry may not be in the long run interests of any early entrant. 


\section{References}

Adner, R. (2004) “A demand-based view of technology life cycles” In J.A.C. Baum and A.M. McGahan, Business Strategy over the Industry Life Cycle: Advances in Strategic Management, 21 (pp. \#\#-\#\#). Oxford UK: JAI/Elsevier.

Agarwal, R., and Bayus, B. (2002) “The market evolution and take-off of new product innovations” Management Science 48(8): 1024-41.

Agarwal, R., Echambadi, R., Franco, A., and Sarkar M. (forthcoming) "Knowledge transfer through inheritance: spinout generation, development and performance” Academy of Management Journal

Agarwal, R., and Gort, M. (1996) "The evolution of markets and entry, exit and the survival of firms" Review of Economics and Statistics 69(4): 567-74.

Agarwal, R., Sarkar, M, and Echambadi, R. (2002) "The conditioning effect of time: a life cycle approach” Academy of Management Journal 45(8): 971-94.

Allison, P. D (1995) Survival Analysis Using the SAS System: A Practical Guide. Cary, NC: SAS Institute.

Baum, J.A.C. (1995) “The changing basis of competition in organizational populations: The Manhattan hotel industry, 1887-1990”Social Forces 74: 177-205.

Baum, J.A.C., and Oliver, C. (1991) “ Institutional linkages and organizational mortality” Administrative Science Quarterly 36: 187-218.

Bayus, B., and Putsis, W (1999) "Product proliferation: an empirical analysis of product line determinants and market outcomes”. Marketing Science 18(2): 137-53.

Bernanke, B. (1983) “Irreversibility, uncertainty, and cyclical investment”. Quarterly Journal of Economics. 98(1): 85-106.

Brown, L. (1981) Innovation Diffusion: A New Perspective. New York: Methuen.

Carroll, G.R., and. Hannan, M.T (1989) “Density delay in the evolution of organizational populations: a model and five empirical tests” Administrative Science Quarterly 34: 411-30.

Christensen, C. M. (1993) “The rigid disk drive industry: a history of commercial and technological turbulence”. Business History Review 67: 531-88.

Christensen, C. M. (1997) The Innovator's Dilemma: When New Technologies Cause Great Firms to Fail. Boston: Harvard Business School Press.

Enos, J. (1962), The Rate and Direction of Inventive Activity, Princeton: Princeton University Press.

Echambadi, R., Sarkar,M, Agarwal, R. and Arroniz, I (2003) "Entry timing and firm survival: the 
moderating effects of firm and industry factors”, working paper.

Freeman, C. Clark, J. and Soete, L. (1982) Unemployment and Technical Innovation: A Study of Long Waves and Economic Development. Westport, CT: Greenwood Press.

Geroski, P (1991) Market Dynamics and Entry. Cambridge, MA: Blackwell.

Geroski, P (1995) “What do we know about entry?” International Journal of Industrial Organization 13: $421-40$.

Ghemawat, P. (1991) Commitment: The Dynamic of Strategy. New York.: Free Press.

Giscard d'Estaing, V. (1986), The Second World Almanac Book of Inventions, New York: Pharos Books.

Golder, P., and Tellis, G. (1997) "Will it ever fly? modeling the takeoff of really new consumer durables” Marketing Science 16(3): 256-70.

Golder, P., and Tellis, G. (1993) “Pioneer advantage: marketing logic or marketing legend?” Journal of Marketing Research 30: 158-70.

Gort, M., and Klepper, S (1982) Time Paths in the Diffusion of Product Innovations. Economic Journal 92: 630-653.

Gort, M., and Konakayama, A. (1982) "A model of diffusion in the production of an innovation," American Economic Review 72(5): 1111-20.

Hannan, M. T., and Carroll, G. (1992) Dynamics of Organizational Populations: Density, Competition, and Legitimation. New York: Oxford University Press.

Henderson, A.D. (1999) "Firm strategy and age dependence: a contingent view of the liability of newness, adolescence, and obsolescence” Administrative Science Quarterly 44: 281-314.

Henderson, R.M., and Clark, K.B. (1990) "Architectural innovation: the reconfiguration of existing product technologies and the failure of established firms” Administrative Science Quarterly 35: 9-30.

Ingersoll, J., and Ross. S.A. (1992) "Waiting to invest: investment and uncertainty” Journal of Business 65: 1-29.

Jewkes, J., Sawers, D., and Stillerman, R. (1958) The Sources of Innovation, London: Macmillian.

Jovanovic, B., and MacDonald, G. (1994) "The life cycle of a competitive industry” Journal of Political Economy 102(21): 322-47.

Kalyanaram, G., Robinson, W.T. and Urban, G.L. (1995) "Order of market entry: established empirical generalizations, emerging empirical generalizations and future research” Marketing Science 14: G212-G22. 
Kerin, R.A., Varadarajan, P.R., and Peterson. R.A. (1992) “First-mover advantage: a synthesis, conceptual framework, and research propositions”. Journal of Marketing 56: 33-52.

Khan, B.Z., and Sokoloff. K.L. (1993) "Schemes of practical utility: entrepreneurship and innovation among the great inventors in the united states, 1790-1865” Journal of Economic History 53 (June): 289-307.

Kohli, R., Lehmann, D.,and Pae, J. (1999), “Extent and impact of incubation time in new product diffusion,” Journal of Product Innovation Management, 16 (2), 134-144.

Klepper, S. (2004). "Pre-entry experience and firm performance in the evolution of the u.s. automobile industry” In J.A.C. Baum and A.M. McGahan, Business Strategy over the Industry Life Cycle: Advances in Strategic Management, 21 (pp. \#\#-\#\#). Oxford UK: $\mathrm{JAI} /$ Elsevier.

Klepper, S. (1996) "Entry, exit, growth and innovation over the product life cycle” American Economic Review, 86: 560-581.

Klepper, S., and Graddy, E. (1990) “The evolution of new industries and the determinants of market structure”. Rand Journal of Economics 21(1): 27-44.

Klepper, S., and Simons. K..(1997) “Technological extinctions of industrial firms: an inquiry into their nature and causes” Industrial and Corporate Change 6(2): 379-460.

Lambkin, M., and Day, G.S. (1989) "Evolutionary processes in competitive markets: beyond the product life cycle” Journal of Marketing 53: 4-20.

Lamoreaux, N.R., and Sokoloff, K.L. (2002) “ Intermediaries in the us market for technology, 18701920” NBER Working Paper 9017(June).

Lieberman, M., and Montgomery, D. (1998) "First-Mover (dis)advantages: retrospective and link with the resource-based view”. Strategic Management Journal 19: 1111-25.

Lieberman, M., and Montgomery, D. (1988) “First-mover advantages” Strategic Management Journal 9 (Summer Special Issue): 41-58.

Mahajan, V., Muller, E. and Bass. F. (1990) “New product diffusion models in marketing: a review and directions for research. Journal of Marketing 54: 1-26.

Mansfield, E. (1962) “Entry, Gibrat's law, innovation and the growth of firms” American Economic Review 52(4): 1023-51.

McDonald, R., and Siegel, D. (1986) “The value of waiting to invest” Quarterly Journal of Economics 101: 707-27.

McGahan, A. (1983) “The effect of incomplete information about demand on preemption” International Journal of Industrial Organization 11(3): 327-346. 
Mensch, G. (1979) Stalemate In Technology: Innovations Overcome The Depression New York: Ballinger.

Miller, K., and. Folta, T. (2002) “Option value and entry timing” Strategic Management Journal 23: 655-65.

Mitchell, W. (1991) "Dual clocks: entry order influences on incumbent and newcomer market share and survival when specialized assets retain their value” Strategic Management Journal 12(2): 85-100.

Moore, G. (1991). Crossing the Chasm. New York: HarperBusiness.

Robinson, W.T., Kalyanaram, G., and Urban, G.L. (1994) "First mover advantages from pioneering new markets: a survey of empirical evidence” Review of Industrial Organization 9: 1-23.

Robinson, W.T., and Min, S. (2002). Is the first to market the first to fail? empirical evidence for industrial goods businesses” Journal of Marketing Research 39(1): 120-28.

Rosegger, G., and Baird, R. (1987) “Entry and exit of makes in the automobile industry 1895-1960” OMEGA 15(2): 93-102.

Rosenberg, N. (1982) Inside the Black Box. New York: Cambridge University Press.

Rosenberg, N. (1994). Exploring the Black Box. New York: Cambridge University Press.

Shapiro, N. (1986) “Innovation, new industries and new firms” Eastern Economic Journal, 12(1): 27-43.

Shepherd, D. A. (1999) Venture capitalists’ assessment of new venture survival” Management Science 45(2): 621-32.

Szymanski, D.M., Troy, L.C. and Bharadwaj, S.G. (1995) "Order of entry and business performance: an empirical synthesis and reexamination”. Journal of Marketing 59(4): 17-34.

Thomson, R. (1986) “Technological change as new product development” Social Concept 3: 3-26.

Trigeorgis, L. (1991) “Anticipated competitive entry and early preemptive investment in deferrable projects” Journal of Economics and Business 43: 143-56.

Tushman, M.L. and Anderson, P. (1986). “Technological discontinuities and organizational environments” Administrative Science Quarterly 31: 439-65.

Utterback, J. (1994) Mastering the Dynamics of Innovation. Boston: Harvard Business School Press.

Utterback, J., and. Abernathy, W. (1975) “A dynamic model of process and product innovation” OMEGA (3): 639-56.

Utterback, J.M., and Suarez, F.F. (1993) “Innovation competition, and industry structure” Research Policy 22 (1): 1-21. 
Vander Werf, P., and Mahon, J. (1997) "Meta-analysis of the impact of research methods on findings of first-mover advantages” Management Science 43(11): 1510-1519.

Yip, G. S. (1982) Barriers to Entry. Lexington, MA: D.C. Heath and Company. 


\section{Appendix}

Table A1: Key Dates for Our Sample of New Industries

\begin{tabular}{lcccc}
\hline Industry & $\begin{array}{c}\text { “Invention” } \\
\text { Year }\end{array}$ & $\begin{array}{c}\text { “Commercialization” } \\
\text { Year }\end{array}$ & $\begin{array}{c}\text { Firm Take- } \\
\text { Off Year }\end{array}$ & $\begin{array}{c}\text { Sales Take- } \\
\text { Off Year }\end{array}$ \\
\hline Phonograph Record & 1877 & 1897 & 1917 & 1919 \\
Outboard Engine & 1905 & 1913 & 1916 & 1936 \\
Electric Blanket & 1914 & 1915 & 1923 & 1952 \\
Dishwasher & 1898 & 1915 & 1951 & 1955 \\
Clothes Washer & 1901 & 1921 & 1923 & 1933 \\
Freon Compressor & 1930 & 1935 & 1938 & 1964 \\
Cathode Ray Tube & 1897 & 1935 & 1943 & 1949 \\
Clothes Dryer & 1930 & 1935 & 1946 & 1950 \\
Electric Razor & 1928 & 1937 & 1938 & 1943 \\
Styrene & 1831 & 1938 & 1943 & 1946 \\
Piezoelectric Crystals & 1880 & 1941 & 1944 & 1973 \\
Home Freezer & 1924 & 1946 & 1947 & 1950 \\
Antibiotics & 1928 & 1948 & 1950 & 1956 \\
Turbojet Engine & 1934 & 1948 & 1949 & 1951 \\
Ball-Point Pen & 1888 & 1948 & 1957 & 1958 \\
Garbage Disposer & 1929 & 1949 & 1953 & 1955 \\
Magnetic Recording Tape & 1928 & 1952 & 1953 & 1968 \\
Heat Pump & 1851 & 1954 & 1960 & 1976 \\
Home Microwave Oven & 1947 & 1970 & 1974 & 1976 \\
Microcomputer & 1962 & 1974 & 1977 & 1982 \\
Home VCR & 1951 & 1974 & 1975 & 1980 \\
Compact Disc Player & 1979 & 1983 & 1984 & 1985 \\
\hline
\end{tabular}


Table 1: Descriptive Statistics and Correlation Matrix for Firm and Industry Characteristics $(\mathrm{N}=25,606)$

\begin{tabular}{|c|c|c|c|c|c|c|c|}
\hline Variable & $\mu$ & $\sigma$ & $\begin{array}{l}\text { Small } \\
\text { Size at } \\
\text { Entry }\end{array}$ & $\begin{array}{c}\text { De alio } \\
\text { at } \\
\text { Entry }\end{array}$ & Age & $\begin{array}{c}\text { Timing } \\
\text { of } \\
\text { Entry }\end{array}$ & $\begin{array}{c}\text { Firm } \\
\text { Density }\end{array}$ \\
\hline $\begin{array}{c}\text { Small Size at } \\
\text { Entry }\end{array}$ & 0.49 & 0.50 & 1.00 & & & & \\
\hline $\begin{array}{l}\text { De alio at } \\
\text { Entry }\end{array}$ & 0.55 & 0.50 & -0.28 & 1.00 & & & \\
\hline Age & 10.76 & 10.78 & -0.15 & 0.07 & 1.00 & & \\
\hline $\begin{array}{c}\text { Timing of } \\
\text { Entry }\end{array}$ & 2.69 & 0.96 & 0.16 & 0.05 & -0.19 & 1.00 & \\
\hline Firm Density & 0.70 & 0.23 & 0.09 & -0.05 & -0.05 & 0.25 & 1.00 \\
\hline
\end{tabular}


Table 2: Summary Survival and Exit Statistics for Entry Cohorts

\begin{tabular}{||l|c|c|c|c|c|}
\hline \multirow{2}{*}{$\begin{array}{c}\text { Cohort } \\
\text { Group }\end{array}$} & $\begin{array}{c}\text { 5-year } \\
\text { Survival rates } \\
(\sigma)\end{array}$ & $\begin{array}{c}\text { Percent of Cohort that Exits } \\
\text { Before } \\
\text { Firm } \\
\text { Take-off }\end{array}$ & $\begin{array}{c}\text { Between } \\
\text { Firm and } \\
\text { Sales } \\
\text { Take-off }\end{array}$ & $\begin{array}{c}\text { Percent of Cohort } \\
\text { After Sales } \\
\text { Take-off }\end{array}$ & $\begin{array}{c}\text { That Did Not Exit } \\
\text { by End of } \\
\text { Sample Period }\end{array}$ \\
\cline { 3 - 6 } Creators & $\begin{array}{c}72 \% \\
(0.02)\end{array}$ & $27 \%$ & $29 \%$ & $33 \%$ & $11 \%$ \\
\hline Anticipators & $\begin{array}{c}67 \% \\
(0.03)\end{array}$ & ---- & $37 \%$ & $49 \%$ & $13 \%$ \\
\hline Followers & $\begin{array}{c}60 \% \\
(0.01)\end{array}$ & ---- & -- & $70 \%$ & $30 \%$ \\
\hline
\end{tabular}


Table 3: Probability of Failure for the Entire Industry Life Cycle ${ }^{a}$ (standard errors in parentheses)

\begin{tabular}{|c|c|c|c|c|}
\hline & $\begin{array}{c}\text { Model 1: } \\
\text { All } \\
\text { Firms } \\
\end{array}$ & $\begin{array}{l}\text { Model 2: } \\
\text { Only } \\
\text { Creators } \\
\end{array}$ & $\begin{array}{c}\text { Model 3: } \\
\text { Only } \\
\text { Anticipators } \\
\end{array}$ & $\begin{array}{l}\text { Model 4: } \\
\text { Only } \\
\text { Followers }\end{array}$ \\
\hline Intercept & $\begin{array}{l}1.69 * \\
(0.11)\end{array}$ & $\begin{array}{c}-1.61^{*} \\
(0.40)\end{array}$ & $\begin{array}{c}-2.31^{*} \\
(0.65)\end{array}$ & $\begin{array}{l}2.69 * \\
(0.16)\end{array}$ \\
\hline $\begin{array}{l}\text { Entry Stage } \\
\text { Creator } \\
\text { Anticipator }\end{array}$ & $\begin{array}{c}-0.84 * \\
(0.08) \\
-0.46^{*} \\
(0.07) \\
\end{array}$ & $\begin{array}{l}--- \\
---\end{array}$ & $\begin{array}{c}--- \\
---\end{array}$ & $\begin{array}{l}--- \\
---\end{array}$ \\
\hline Timing of Entry & --- & $\begin{array}{l}-0.04 \\
(0.15)\end{array}$ & $\begin{array}{l}-0.13 \\
(0.13)\end{array}$ & $\begin{array}{c}-0.29 * \\
(0.05)\end{array}$ \\
\hline $\begin{array}{l}\text { Firm Factors } \\
\text { Small Size at Entry } \\
\text { De alio at Entry } \\
\text { Age } \\
\text { Age }^{2}\end{array}$ & $\begin{array}{c}-0.09 * \\
(0.04) \\
-0.34 * \\
(0.04) \\
-0.02 * \\
(0.01) \\
0.0001 \\
(0.0002) \\
\end{array}$ & $\begin{array}{c}0.15 \\
(0.18) \\
-0.15 \\
(0.18) \\
-0.03 \\
(0.02) \\
0.0001 \\
(0.0003) \\
\end{array}$ & $\begin{array}{c}0.32 * \\
(0.13) \\
-0.17 \\
(0.12) \\
-0.04^{*} \\
(0.01) \\
0.001^{*} \\
(0.0003) \\
\end{array}$ & $\begin{array}{c}-0.16^{*} \\
(0.04) \\
-0.31^{*} \\
(0.04) \\
-0.03^{*} \\
(0.01) \\
0.0001 \\
(0.0002) \\
\end{array}$ \\
\hline $\begin{array}{l}\text { Industry Factors } \\
\text { Firm Density } \\
\text { Firm Density }^{2}\end{array}$ & $\begin{array}{c}-4.21 * \\
(0.37) \\
3.23 * \\
(0.29) \\
\end{array}$ & $\begin{array}{l}-2.21 \\
(1.39) \\
2.78 * \\
(1.22)\end{array}$ & $\begin{array}{c}0.13 \\
(1.64) \\
0.57 \\
(1.26)\end{array}$ & $\begin{array}{c}-4.72 * \\
(0.47) \\
3.57 * \\
(0.36)\end{array}$ \\
\hline -Log Likelihood & -7333.18 & -648.37 & -1297.08 & -5215.93 \\
\hline Number of Observations & 25,606 & 2,921 & 5,932 & 16,753 \\
\hline
\end{tabular}

${ }^{a}$ Although not reported here, estimates for 21 product category dummy variables are included in each model.

* significant at 5\% level or better (two-tailed) 
Table 4: Probability of Failure for Linear and Non-Linear Effects of Timing of Entry ${ }^{\mathrm{a}}$ (standard errors in parentheses)

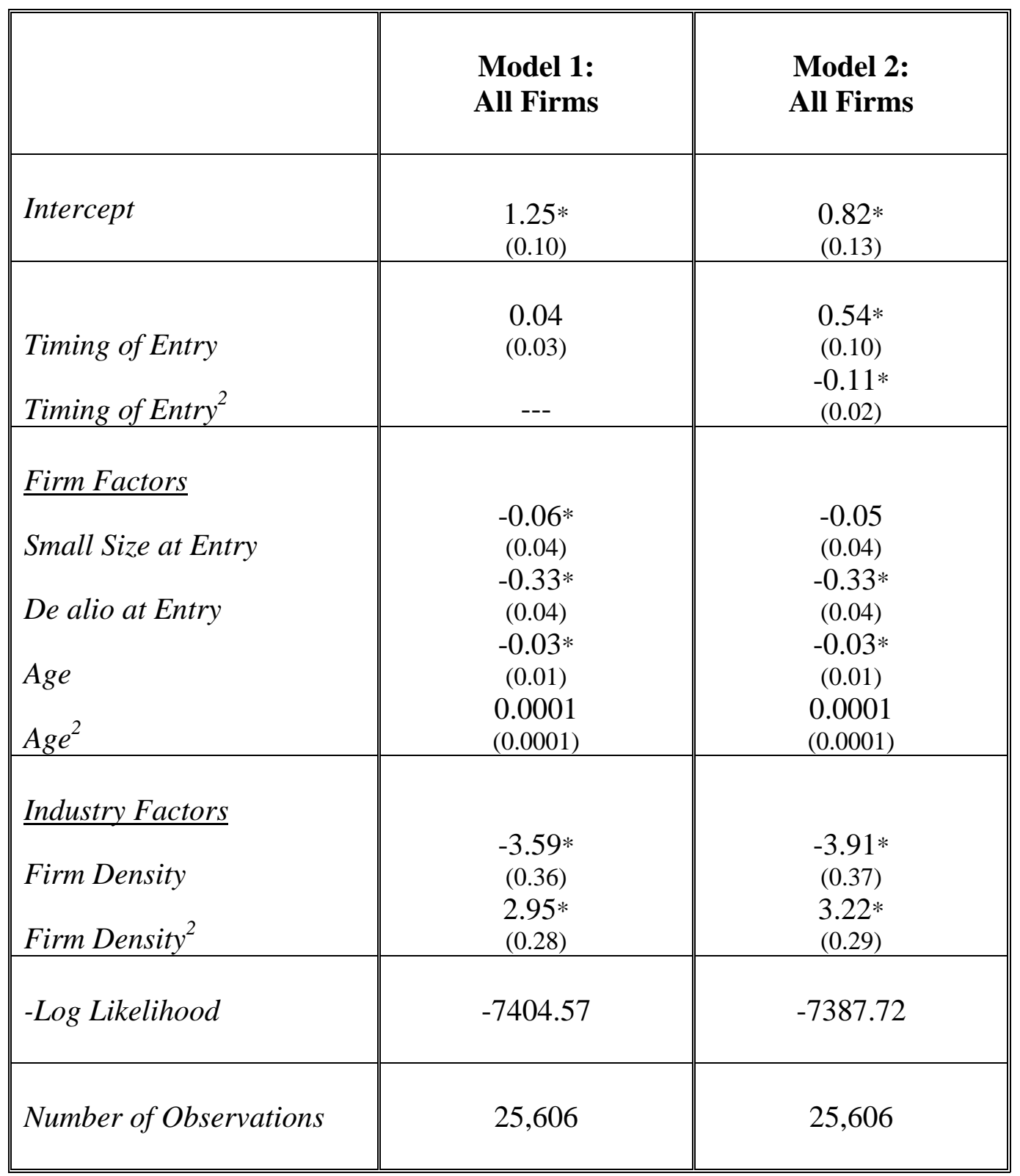

${ }^{a}$ Although not reported here, estimates for 21 product category dummy variables are included in each model.

* significant at 5\% level or better (two-tailed) 
Figure 1: The Evolution of Market Structure for Product Innovations (source: Agarwal and Bayus 2002)
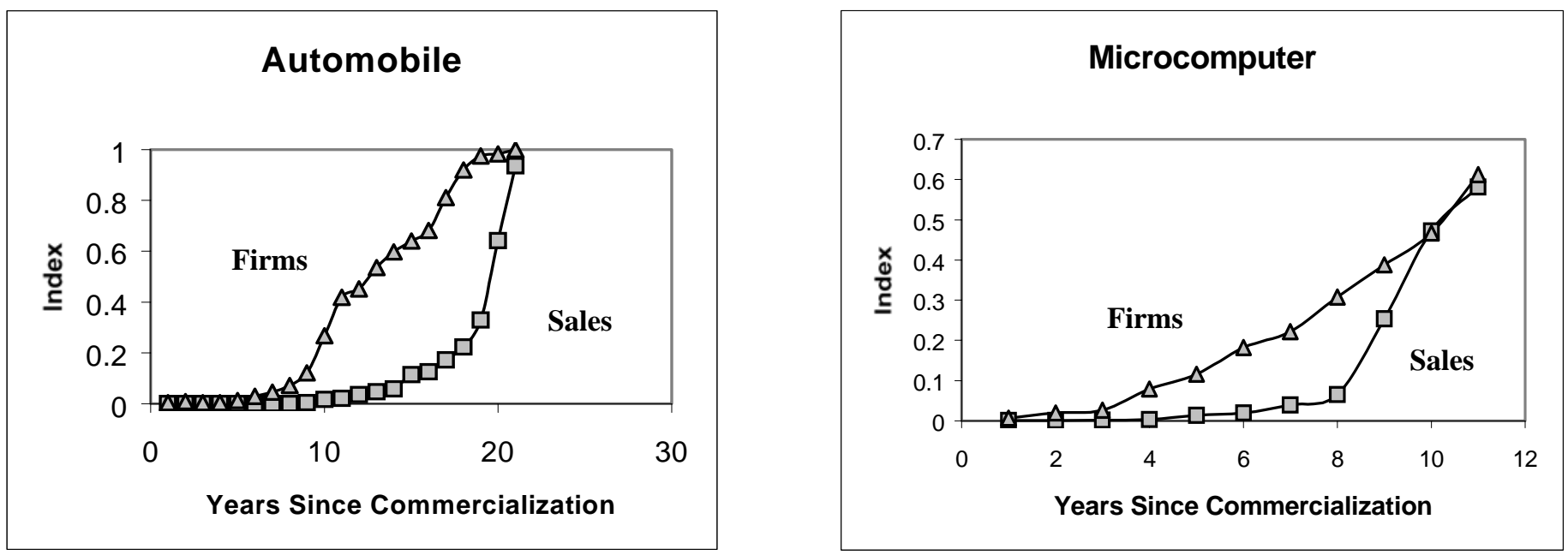
Figure 2: Descriptive Statistics for the Market Evolution of Product Innovations (Means) (source: Agarwal and Bayus 2002)

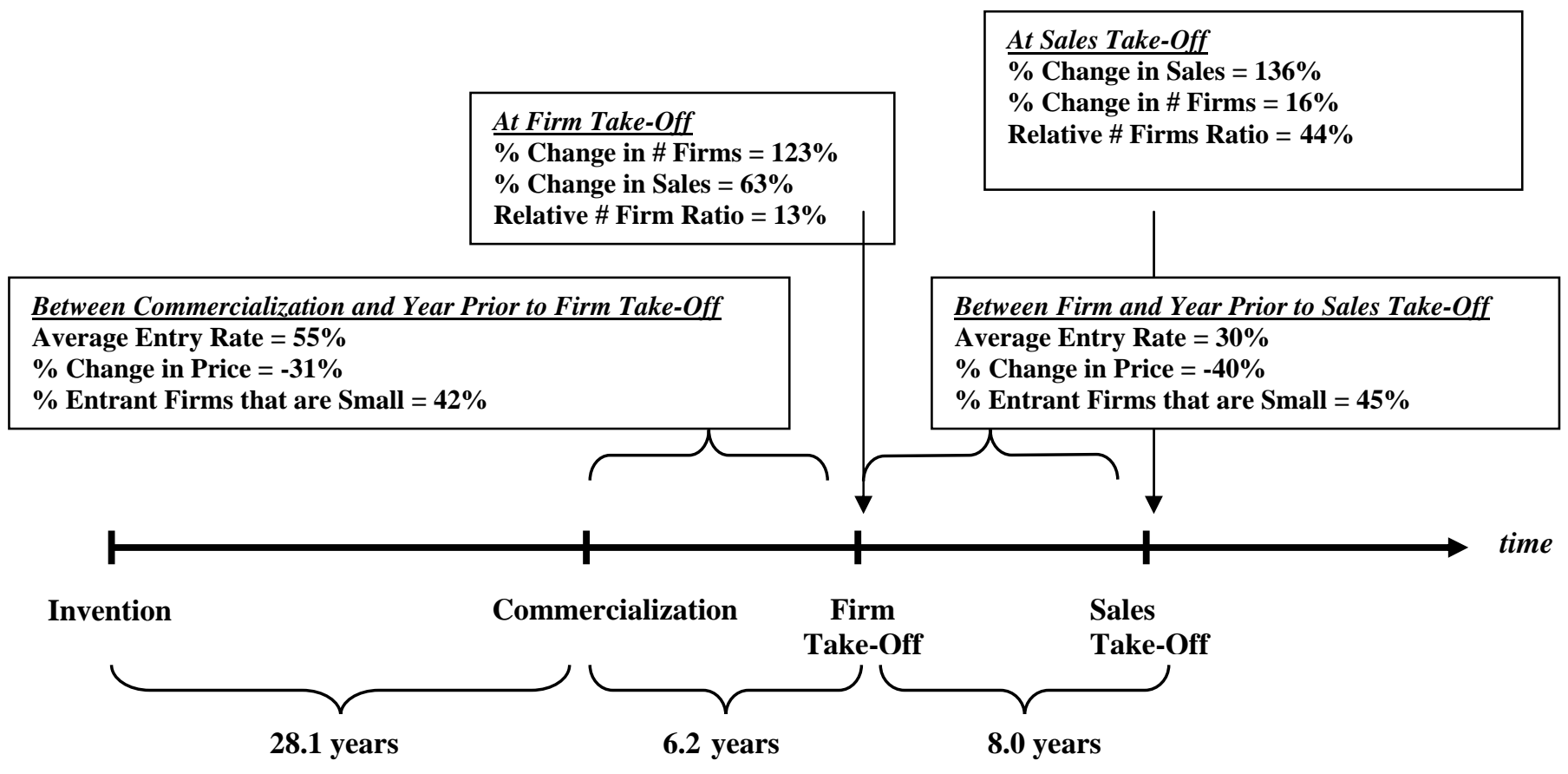

